\title{
The Characteristics of Motile and Static Semen of Swamp Buffalo in Teaching and Experimental Farm Lombok
}

\author{
Maskur $^{1 *}$, Chairussyuhur Arman ${ }^{1}$, Syahrudin Said ${ }^{2}$ \\ ${ }^{1}$ Faculty of Animal Science, University of Mataram, Lombok, West Nusa Tenggara Province, \\ Indonesia \\ ${ }^{2}$ Research Center for Biotechnology, Indonesia Institute of Sciences \\ *Corresponding E-mail: chairussyuhur.arman@yahoo.com
}

Diterima: 9 Juli 2020/Disetujui: 27 Oktober 2020

\begin{abstract}
ABSTRAK
Penampungan semen pada kerbau seringkali menghasilkan semen yang tidak menunjukkan adanya pergerakan massa spermatozoa. Semen seperti ini disebut semen statik, sedangkan semen yang menunjukkan adanya pergerakan massa spermatozoa disebut semen motil. Penelitian dilaksanakan untuk mengevaluasi kualitas semen dan spermatozoa pada semen motil dan semen statik kerbau lumpur. Sumber semen diperoleh dari 3 ekor kerbau lumpur dengan kisaran umur 2.5 sampai 3,0 tahun dan berat badan 441 sampai $477 \mathrm{~kg}$ yang dipelihara di Teaching dan Experimental Farm, Fakultas Peternakan Universitas Mataram. Sebanyak sembilan puluh delapan ejakulat terdiri atas 52 ejakulat semen motil dan 46 ejakulat semen statik digunakan pada penelitian ini untuk mengevaluasi kualitas semen dan spermatozoa pada ketiga sumber semen tersebut. Kejadian ejakulat statik adalah sekitar 47 persen yang bervariasi dari pejantan ke pejantan. Penelitian menunjukkan bahwa perbedaan di antara kerbau jantan didapati tidak signifikan untuk semua karakteristik semen statik, kecuali volume semen. Ketika data karakteristik semen dari ketiga kerbau jantan disatukan, ejakulat statik menunjukkan $\mathrm{pH}$, total spermatozoa abnormal dan ekor bengkok yang lebih tinggi $(p<0,05)$ dibandingkan dengan ejakulat motil. Sebaliknya, ejakulat statik menunjukkan penurunan volume ejakulat, konsentrasi sperma dan spermatozoa hidup yang signifikan $(\mathrm{p}<0,05)$. Diperlukan penelitian lebih lanjut tentang kesesuaian semen motil kerbau lumpur yang dipreservasi dalam keadaan cair dan beku.
\end{abstract}

Kata kunci: Semen Motil, Statik, Kerbau Lumpur

\begin{abstract}
Semen collection in buffalo often produces semen which does not show any movement of spermatozoa mass. That type of semen is called static semen, while semen that shows the movement of spermatozoa mass is called motile semen. These studies were undertaken to evaluate the semen and spermatozoa characteristics in both motile and static semen of swamp buffalo. Semen was collected from three buffalo bulls aged 2.5 to 3.0 years with their body weight ranging from $441-477 \mathrm{~kg}$ and maintained at Teaching and experimental Farm, Faculty of Animal Science University of Mataram. Ninety eight ejaculates (52 motile semen and 46 static semen) were collected during the period of study. The occurrence of static semen was about 47 percent with a bull to bull variation. The study indicated that the difference between the bulls was not significant for all static semen characteristics, except for semen volume. When semen data characteristics of the three bulls were pooled, static ejaculates had significantly $(\mathrm{p}<0.05)$ higher $\mathrm{pH}$, total abnormal spermatozoa and bent tail than that of motile ejaculates. Conversely, static ejaculates had significantly $(p<0.05)$ lower ejaculate volume, sperm concentration and live spermatozoa. Further studies on the suitability of motile semen of swamp buffalo to be preserved in liquid and frozen states are needed.
\end{abstract}

Keywords: Semen, Motile, Static, Swamp Buffalo 


\section{INTRODUCTION}

In West Nusa Tenggara (WNT) Province, the predominant buffalo raised by smallholder farmers is the swamp type. As an integral part of the farming system, swamp buffaloes in the province are largely raised for draught, produced meat and milk. Despite its importance for the production of meat and milk, it has not received sufficient attention regarding the improvement of breeding practices. Recently the central government of the Republic of Indonesia has imported a total of 10,000 tons of buffalo meat from India because domestic supplies of buffalo meat production are limited. The importation of buffalo meat was considered as supplementation of cattle meat which is the main supplier of meat to fulfill domestic consumers' demand.

Data from Statistical Central Agency (SCA, 2017) recorded that in Indonesia, buffalo population continues to decline around 7.800 head per year from 2003 to 2011 with the rate of decrease $0.58 \%$. Similarly, buffalo population in WNT Province decreased from 155.307 head in 2009 to 128.335 head in 2016. The population in 2016 represents $9.26 \%$ of buffalo population in Indonesian (WNT Province in Figures, 2017).

One way to enhance population and improve the productivity of local buffalo in Indonesia, especially in WNT Province could be by implementing reproductive technologies. One of the technologies that have tremendously contributed to the genetic improvement and development of animal production is artificial insemination (Nuti, 1997). Under field conditions of WNT Province, it is difficult to find genetically superior bulls to cover breeding buffaloes through natural services. So, it is necessary that maximum number of females be served with the quality frozen semen of the bulls of superior genetic constitution. Therefore, AI with high quality frozen semen seems the only way through which a sizable buffalo population can be covered in WNT Province.

In order to implement AI technology, requirements of the best semen quality for processing frozen semen from selected potential swamp buffalo sires are absolutely important. Semen volume, concentration of spermatozoa, proportion of dead and abnormal spermatozoa, and motility of spermatozoa are recognized as important indices of semen quality and significantly correlated with freezability and/or fertility of bovine semen (Fiaz et al., 2010). Semen producing ability and quality of individual bull are essentials to ensure the supply of superior quality germplasm for maintaining the production performance in future progeny of individual breed in the country (Patel and Siddiquee, 2013). Recent studies have shown that buffalo semen can be preserved just like bovine semen. There are a number of diluents and cryoprotectants, which are suitable for freezing buffalo semen, but there is limited information available on the semen characteristics of the species (Sansone et al., 2000).

Studies on physical semen characteristics of buffalo bulls have been conducted by several workers in different Indian breeds such as Nili-Ravi (Javed et al., 2000), Murrah (Bhakat et al., 2011) and Kundhi (Kiani et al., 2014) buffaloes as well as swamp buffaloes in Malaysia 
(Jainudeen et al., 1981/1982), in Indonesia (Amin et al., 1999), Thailand (Koonjaenak et al., 2007) and India (Ahmed et al., 2015). However, little work if none is available under WNT Province conditions. Knowledge of factors affecting sperm production and semen quality is of great importance with regard to reproductive efficiency and thus genetic improvement of farm animals. Evaluation of bull semen in the laboratory through assessment of ejaculate volume, sperm concentration, wave motion, sperm motility of the fresh and post-thaw semen are valuable in order to discard semen of poor quality (Christensen et al., 1999).

Kumar et al. (1993) stated that freshly collected buffalo semen sometimes does not show any mass activity and such non-motile semen samples designated as static or zero ejaculates were previously discarded. The work on the seminal attributes and cytomorphological characteristics of buffalo semen has been extensively reported in the literature, but reports on the static or non-motile ejaculates in the buffalo bulls are very meagre in the literature (Kumar et al., 1993). Hence, the present work was carried out with the objective to study the characteristics of semen and spermatozoa in both motile and static semen of swamp buffalo.

\section{MATERIALS AND METHODS}

\section{Animals}

Three swamp buffalo bulls
maintained at the Teaching and Experimental Farm belongs to Faculty of Animal Science, University of Mataram, Lombok, West Nusa Tenggara Province were used in the present investigation during the period of April 2017 till the end of December 2017 as semen donors. The age of bulls were 2.5 to 3.0 years old and had body weight range of 441 and $477 \mathrm{~kg}$. They were stall fed with grass, fodder and concentrates. The bulls were allowed to wallow in small pond once a day during the hot hours and then brought back to the shed for cleaning the mud by splashing water over the body.

\section{Reaction Time}

Reaction time is the time taken by a breeding bull for ejaculation, after it is brought to a female dummy, in case of semen collection in artificial vagina (Capitan et al., 1990). Records were made in seconds with the aid of a stop watch.

\section{Semen Collection}

Semen samples were collected between 07:00-08:00 $\mathrm{h}$ on a given day at weekly intervals for eight-month period using an artificial vagina (AV). The AV was assembled and maintained at $42^{\circ} \mathrm{C}$ until used for collection. A lubricant was applied to the inner sleeve of the mounting side of the AV. Prior to semen collection 2 false mounts were allowed on a restrained male dummy. At the third mount, semen was collected into a graduated collection tube attached to the $\mathrm{AV}$ which was covered by an insulator to prevent sperms from cold shock. After collection, semen was transferred to laboratory and maintained at $37^{\circ} \mathrm{C}$ in a water bath for initial evaluation.

\section{Semen Evaluation}

The following parameters were evaluated in fresh swamp buffalo bull semen; semen volume, color, $\mathrm{pH}$, sperm 
mass and progressive motility, concentration, viability and abnormality. The volume of semen collected was directly read from the calibrated collection tube and recorded in $\mathrm{ml}$. The color of semen was graded as creamy, milky, watery and abnormal. A universal $\mathrm{pH}$ paper was used to approximate the $\mathrm{pH}$ of the semen. A drop of pure and undiluted semen was placed in the middle of the $\mathrm{pH}$ paper and the color resulting from it matched to the standard colors.

The mass motility of semen was recorded by placing a small drop of neat semen on a warmed glass slide without cover slip under low magnification $(10 \mathrm{X})$ and scored on a scale of 1-3 $(+1=$ with slight movement, individual sperms do not move out of the field, $+2=$ no swirls formed but have excellent progressive movement, $+3=$ have vigorous movement, vigorous swirls are present) (Capitan et al., 1990). Motility, as a percentage of individually motile spermatozoa, was by examining $20 \mu \mathrm{L}$ of fresh diluted semen dropped on a warmed glass slide $\left(37^{\circ} \mathrm{C}\right)$ and allowed to spread uniformly under the cover slip. Motility percentage was scored using 400X magnification with a phase contrast microscope on the basis of spermatozoa with normal forward progressive movement, while those showing circling movements or those oscillating at one place were regarded as immotile.

Sperm concentration per $\mathrm{ml}$ of semen was estimated manually in two separate counting chambers using Haemocytometer (Improved Neubauer's chamber) method as described by Hafez (1987). For counting sperms, $25 \mu \mathrm{L}$ of semen was added to $4975 \mu \mathrm{L}$ of sodium bicarbonate buffer and a dilution of 1:200 was obtained. The diluted sample was charged in a counting chamber and counted under a phase contrast microscope at 400X magnification.

Sperm viability (live-dead) was determined using eosin-nigrosin stain. The smears were prepared by mixing one drop of semen sample with two drops of the stain on a warmed slide and immediately spreading the stain with one edge of a second slide. After air-drying, the smear was studied under a phase contrast microscope (400X magnification) for unstained heads of sperm (live) and stained/partial stained heads of sperm (dead). A total of 100 sperm was counted to determine live and dead percentages of sperm. Morphological examination of sperm abnormalities includes bent tail, coiled tail and loose heads. The same slide which is used for counting sperm viability was used for calculating morphological abnormality under a phase contrast microscope (400X magnification). About 100 spermatozoa were counted in different fields and the percentage of abnormal spermatozoa was calculated.

\section{Statistical Analysis}

The statistical program, IBM SPSS Statistics for window (version 22) was used for obtaining mean \pm standard error of mean (SEM), and the means were compared using Duncan's Multiple Range Tests.

\section{RESULTS AND DISCUSSION}

\section{Motile and static ejaculates}

Percentages of the occurence of motile and static ejaculates in three 
swamp buffalo bulls reared under Teaching and Experimental Farm conditions in Lombok are given in Table 1.

Table 1. Status of motile and static ejaculates in three swamp buffalo bulls

\begin{tabular}{ccccccc}
\hline $\begin{array}{c}\text { Bull } \\
\text { number }\end{array}$ & $\begin{array}{c}\text { Motile semen } \\
\text { (ejaculates) }\end{array}$ & $\%$ & $\begin{array}{c}\text { Static semen } \\
\text { (ejaculates) }\end{array}$ & $\%$ & $\begin{array}{c}\text { Total number } \\
\text { of ejaculates }\end{array}$ & $\%$ \\
\hline 1 & 23 & 67,65 & 11 & 32,35 & 34 & 100,00 \\
2 & 24 & 70,59 & 10 & 29,41 & 34 & 100,00 \\
3 & 5 & 16,67 & 25 & 83,33 & 30 & 100,00 \\
Overall & 52 & 53,06 & 46 & 46,94 & 98 & 100,00 \\
\hline
\end{tabular}

In initial evaluation, it was found that 47 percent of the ejaculates obtained was static semen, while 53 percent was motile semen. This is higher than that of Nainar et al. (1990) and Kumar et al. (1993) reported in which static semen in Murrah buffalo presenting 40 and 30 percent, respectively. The incidence was found to be due to individual variation as certain bulls were unique in producing static semen (Nainar et al., 1990). In the present study, 54.35 percent (25 out of 46) static semen was observed in Bull
No. 3. The semen and spermatozoa characteristics of static semen and motile semen were presented consecutively in Table 2, 3 and Table 4.

\section{Characteristics of Motile Semen}

The mean $( \pm$ SEM) of characteristics of motile semen and reaction time from three swamp buffalo bulls reared under Teaching and Experimental conditions in Lombok is presented in Table 2. There was no significant $(p>0.05)$ differences in semen volume, color, viscosity and $\mathrm{pH}$ among the three bulls (Table 1).

Table 2. Characteristics of motile semen and reaction time from three buffalo bulls reared under Teaching Farm conditions in Lombok, WNT Province (Mean \pm Sem)

\begin{tabular}{|c|c|c|c|c|}
\hline Variables & $\begin{array}{l}\text { Bull 1 } \\
(\mathrm{n}=23)\end{array}$ & $\begin{array}{c}\text { Bul 2 } \\
(n=24)\end{array}$ & $\begin{array}{l}\text { Bul 3 } \\
(n=5)\end{array}$ & $\begin{array}{l}\text { Overall } \\
(\mathrm{n}=52)\end{array}$ \\
\hline Volume (ml) & $3,47 \pm 1,25$ & $1,30 \pm 0,12$ & $0,78 \pm 0,16$ & $2,21 \pm 0,57$ \\
\hline Color & milky white & milky white & milky white & milky white \\
\hline Viscosity & watery-thick & watery-thick & watery-thick & watery-thick \\
\hline $\mathrm{pH}$ & $6,35 \pm 0,10$ & $6,38 \pm 0,10$ & $6,60 \pm 0,40$ & $6,38 \pm 0,07$ \\
\hline Mass movement (0-3 scales) & $2,78 \pm 0,11^{\mathrm{a}}$ & $2,92 \pm 0,08^{\mathrm{a}}$ & $2,20 \pm 0,37^{\mathrm{b}}$ & $2,79 \pm 0,07$ \\
\hline Progressive motility (\%) & $81,74 \pm 2,75$ & $81,50 \pm 3,58$ & $74,00 \pm 4,85$ & $80,88 \pm 2,09$ \\
\hline Concentration $\left(\mathrm{x} 10^{7}\right.$ sperm $\left./ \mathrm{ml}\right)$ & $167,65 \pm 15,07^{\mathrm{a}}$ & $178,54 \pm 17,32^{\mathrm{a}}$ & $326,40 \pm 109,59^{\mathrm{b}}$ & $187,94 \pm 15,39$ \\
\hline Live sperm $(\%)$ & $96,78 \pm 0,44^{\mathrm{a}}$ & $97,13 \pm 0,34^{\mathrm{a}}$ & $93,60 \pm 1,50^{\mathrm{b}}$ & $96,63 \pm 0,31$ \\
\hline Abnormal spermatozoa (\%) & $8,65 \pm 1,47$ & $6,25 \pm 0,78$ & $7,20 \pm 2,62$ & $7,40 \pm 0,79$ \\
\hline - Bent tail $(\%)$ & $4,43 \pm 1,10$ & $2,79 \pm 0,44$ & $3,60 \pm 1,69$ & $3,60 \pm 0,55$ \\
\hline - Coiled tail (\%) & $1,61 \pm 0,45$ & $1,00 \pm 0,22$ & $1,60 \pm 0,98$ & $1,33 \pm 0,24$ \\
\hline - Loose head (\%) & $2,61 \pm 0,72$ & $2,46 \pm 0,52$ & $2,00 \pm 0,63$ & $2,48 \pm 0,40$ \\
\hline Reaction time (sec) & $26,00 \pm 5,38^{\mathrm{a}}$ & $49,79 \pm 19,73^{\mathrm{a}}$ & $115,00 \pm 41,19^{b}$ & $45,54 \pm 10,58$ \\
\hline
\end{tabular}

$\mathrm{n}:$ number of collected samples

Figures with similar superscript within the same row are not significantly different from each other at level $(\mathrm{p}<0.05)$. 


\section{Semen Volume, Color, Viscosity, and pH}

The overall mean of semen volume was $2,21 \pm 0,57 \mathrm{ml}$, the color was milky white and the viscosity ranged from watery to thick. The semen $\mathrm{pH}$ was recorded to be $6,38 \pm 0,07$ which tended towards acidic. The mean volume of ejaculate agreed with that reported by Kumar et al., (1993) who recorded of $2.56 \pm 0.10 \mathrm{ml}$ in motile semen of Murrah buffalo. However, Dixit et al. (1984) reported higher semen volume $(4.66 \pm 0.21 \mathrm{ml})$ obtained from buffalo bulls. Semen $\mathrm{pH}$ of swamp buffalo found in the present study was slightly lower than Kumar et al. (1993) recorded in Murrah buffalo semen $\mathrm{pH}(6.72 \pm 0.02$ $\mathrm{ml}$ ). With regard to the color, the study was in contrast to the findings of Dixit et al. (1984) who observed $90 \%$ the color of buffalo semen was creamy and also different from Gunarajasingam and Abeygunawardena (1995) who recorded buffalo semen color was cloudy to creamy. However, the viscosity of semen observed in the study was similar to that of Dixit et al. (1984) has reported.

The variation in the semen volume in various breeds of buffaloes might be due to differences in age, body weight, season and frequency of semen collection (Ghodasara et al., 2016).

\section{Mass Movement}

Mass movement of spermatozoa in motile semen of Bulls No. 1 and 2 was higher $(p<0.05)$ than that of Bull No. 3 . However, no significant differences in percent progressive motility among the three bulls were observed. In the present study the overall mean of mass movement of swamp buffalo semen was
$2,79 \pm 0,07$. This was slightly higher than mass movement of Murrah buffalo motile semen noted by Kumar et al. (1993), i.e. $2.57 \pm 0.04$. In fact, our finding was lower than mass movement of swamp buffalo semen as recorded by Ahmed et al. (2015), i.e. $3.78 \pm 0,05$. However, the overall mass movement of spermatozoa in the study was within the normal range of spermatozoa mass movement of swamp buffalo (Amin et al., 1999; Koonjaenak et al., 2007), Kundhi buffalo (Kiani et al., 2014) and Nili-Ravi buffalo (Javed et al., 2000) semen. Mass movement of spermatozoa has been an important attribute for acceptance or rejection of the ejaculate for further processing and use in artificial insemination (Patel and Siddiquee, 2013).

\section{Progressive Motility}

The mean percentages of progressive motility of bufffalo spermatozoa in motile semen showed non-significant difference among the three bulls. The overall mean progressive motility was $80,88 \pm 2,09$ percent. This in agreement with that of progressive motility of spermatozoa from Asian swamp buffaloes (Amin et al., 1999; Koonjaenak et al., 2007; Ahmed et al. 2015) and Indian buffalo breeds (Ghodasara et al., 2016; Dixit et al.,1984; Kumar et al., 1993). However, the mean progsessive motile sperm in the present study was higher than the findings of Jainudeen et al. (1982) in Malaysian swamp buffalo semen (67.00 \pm 7.00 percent), Kiani et al. (2014) in Kundhi (66.5 \pm 1.5 percent) and Javed et al. (2000) in Nili-Ravi (56.89 \pm 0.65 percent) buffalo semen. On the other hand, mean progressive motile sperm in this study was lower compared 
with that of progressive motile sperm $(86.3 \pm 5.33$ per cent) recorded in Indian buffalo (Gunarajasingam and Abeygunawardena, 1995).

\section{Concentration of Spermatozoa}

The concentration of spermatozoa per $\mathrm{ml}$ semen in Bull No. 3 was significantly higher $(\mathrm{p}<0.05)$ than that of Bulls No. 2 and No. 1. Although the concentration of spermatozoa of Bull No. 2 was higher than Bull No.1, the difference was not significant $(p>0.05)$. The overall mean concentration of spermatozoa

$(187,94 \pm 15,39$ $\mathrm{x} 10^{7} \mathrm{sperm} / \mathrm{ml}$ ) in motile semen was higher than that reported in Indonesian (Amin et al.,1999) and Indian swamp buffalo bulls (Kumar et al.,1993; Gunarajasingam and Abeygunawardena, 1995; Ghodasara et al., 2016). However, mean concentration of spermatozoa in the present study was lower than that reported by Jainudeen et al. (1982) in Malaysia $\left(1.06 \pm 0.62 \times 10^{9} / \mathrm{ml}\right.$ semen), Dixit et al. (1984) in India (1.14 \pm 0.10 $\mathrm{x} 10^{9} / \mathrm{ml}$ semen) and Koonjaenak et al. (2007) in Thailand $\left(1.2 \pm 0.0 \times 10^{9} / \mathrm{ml}\right.$ semen). Variation in spermatozoa concentrations between the present and other studies could be ascribed to individual spermatozoa production potentiality (Ghodasara et al., 2016).

\section{Live Spermatozoa}

The numbers of live spermatozoa in motile semen of Bulls No. 2 and No. 1 were significantly higher $(p<0.05)$ than that of Bull No. 3. In the present study, the overall mean of live spermatozoa was recorded to be $96,63 \pm 0,31$ percent. This was in close proximity with that reported by Dixit et al. (1984), however, higher than percentages of live buffalo spermatozoa counted by Jainudeen et al. (1982), Kumar et al. (1993), Gunarajasingam and Abeygunawardena (1995), Koonjaenak et al. (2007), Mahmoud et al. (2013) and Ghodasara et al. (2016). The variation in live spermatozoa count has been attributed to breed, season and frequency of collection (Ghodasara et al., 2016).

\section{Abnormal Spermatozoa}

The average percentages of abnormal spermatozoa in motile semen (classified as bent, coiled tails and loose heads) did not differ $(p>0.05)$ between the bulls. The overall mean of abnormal spermatozoa was $7,40 \pm 0,79$ percent. This value was lower than that of abnormal spermatozoa in motile Nili-Ravi bull semen noted by Kumar et al. (1993), i.e. $12.51 \pm 0.11$ percent. In the current study, the comparable values for overall mean of bent, coiled tails and loose heads was recorded in swamp buffalo bull semen by Koonjaenak et al. (2007) (2.87 \pm 0.06 , $4.15 \pm 0.15$, and $5.44 \pm 0.11$ percent, respectively).

\section{Reaction Time}

In this study, reaction time is considered as the time elapsed from introducing the bull to the teaser and exteriortion of penis (Ramadhan et al., 2009). As indicated in Table 1 , reaction time was significantly lower $(\mathrm{p}<0.05)$ in Bulls No. 1 and No. 2 compared with Bull No.3. However, the difference in reaction time between the two previous bulls was not significant $(p>0.05)$. The overall mean of reaction time was recorded to be $45,54 \pm 10,58 \mathrm{sec}$. This value was in contrast with that of Capitan 
et al. (1990) reported in which the total mean reaction time was $29.79 \mathrm{sec}$ in Murrah bulls in the Philippines. However, our finding was lower with respect to those reported in Murrah buffalo in India $(221.03 \pm 14.50$ sec: Kumar et al., 1993; 99.00 $\pm 15.54 \mathrm{sec}$ for control group that given a single shower per day and $129.41 \pm 25.47 \mathrm{sec}$ for experimental group that given four shower per day, respectively: Singh et al., 2001) and in Egyptian buffalo (70.8 \pm 8.74 sec: Ramadan et al. 2009).
Similar with other characteristics, the variation in total abnormal spermatozoa could be due to difference in breed, season, frequency of semen collection, sex drive of bull, etc. (Ghodasara et al., 2016).

\section{Characteristics of Static Semen}

The mean $( \pm$ SEM) of characteristics of static semen and reaction time from three swamp buffalo bulls reared under Teaching and Experimental conditions in Lombok is presented in Table 3.

Table 3. Characteristics of static semen and reaction time from three buffalo bulls reared under Teaching Farm conditions in Lombok, WNT Province (Mean \pm Sem)

\begin{tabular}{lcccc}
\hline Variables & $\begin{array}{c}\text { Bull 1 } \\
(\mathrm{n}=11)\end{array}$ & $\begin{array}{c}\text { Bul } \\
2(\mathrm{n}=10)\end{array}$ & $\begin{array}{c}\text { Bul 3 } \\
(\mathrm{n}=25)\end{array}$ & \multicolumn{1}{c}{$\begin{array}{c}\text { Overall } \\
(\mathrm{N}=46)\end{array}$} \\
\hline Volume (ml) & $1,28 \pm 0,36^{\mathrm{a}}$ & $0,96 \pm 0,17^{\mathrm{ab}}$ & $0,63 \pm 0,08^{\mathrm{b}}$ & $0,86 \pm 0,11$ \\
Color & milky white & milky white & milky white & milky white \\
Viscosity & watery-thick & watery-thick & watery-thick & watery-thick \\
$\mathrm{pH}$ & $6,91 \pm 0,09$ & $6,70 \pm 0,15$ & $6,80 \pm 0,08$ & $6,80 \pm 0,06$ \\
Concentration (x107 sperm/ml) & $162,45 \pm 26,49$ & $116,30 \pm 21,25$ & $146,98 \pm 14,83$ & $144,01 \pm 11,24$ \\
Live sperm (\%) & $95,45 \pm 0,86$ & $93,60 \pm 0,95$ & $94,36 \pm 0,69$ & $94,46 \pm 0,48$ \\
Abnormal spermatozoa (\%) & $12,91 \pm 3,51$ & $12,10 \pm 1,83$ & $10,44 \pm 0,81$ & $11,39 \pm 1,01$ \\
- Bent tail (\%) & $7,73 \pm 3,59$ & $6,80 \pm 1,96$ & $4,88 \pm 0,82$ & $5,98 \pm 1,04$ \\
- Coiled tail (\%) & $1,55 \pm 0,47$ & $1,40 \pm 0,54$ & $2,48 \pm 0,59$ & $2,02 \pm 0,36$ \\
- Loose head (\%) & $3,73 \pm 1,14$ & $3,90 \pm 1,60$ & $3,08 \pm 0,58$ & $3,41 \pm 0,53$ \\
Reaction Time (sec) & $63,60 \pm 18,56$ & $54,14 \pm 19,26$ & $84,49 \pm 26,07$ & $72,90 \pm 15,34$ \\
\hline
\end{tabular}

$\mathrm{n}:$ number of collected samples

Figures with similar superscript within the same row are not significantly different from each other at level $(\mathrm{p}<0.05)$.

The study indicated that the difference between the bulls was not significant for all static semen characteristics, except for semen volume. The overall volume of static semen was lower than those reported by Nainar et al. (1990) and Kumar et al. (1993) in Murrah buffaloes, but it agreed with the result reported by Kumar et al. (1993) in Murrah buffalo bulls $(0,80 \pm 0,06)$. The overall live spermatozoa in static semen observed $(94,46 \pm 0,48$ percent $)$ in the present study was higher than that of Nainar et al. (1990) and Kumar et al. (1993) reported in Murrah buffalo breed. Conversely, the overall abnormal spermatozoa were lower than that reported by Kumar et al. (1993) in Murrah buffalo in which the bent, coiled tails and loose heads of spermatozoa were $\quad 4.20 \pm 0.18, \quad 3.80 \pm 0.27$, and $6.25 \pm 0.16$ percent, respectively.

The overall reaction time in swamp buffalo was found to be $72,90 \pm 15,34 \mathrm{sec}$ 
which was shorter than that of Murrah buffalo, namely $254.06 \pm 17.06 \mathrm{sec}$ reported by Kumar et al. (1993) in Murrah buffalo bulls. Kumar et al. (1993) reported that the reaction time when the bulls donated static semen was significantly higher than when motile semen were obtained. This is in good agreement with the findings of the present study (see Tables 1 and 2).

\section{Semen and Spermatozoa Characteristics in Motile and Static Semen}

The mean $( \pm$ SEM $)$ of different seminal characteristics of motile and static semen of swamp buffalo bulls reared under Teaching Farm conditions was presented in Table 4.

Table 4. Characteristics of motile and static semen and reaction time of buffalo bulls reared under Teaching Farm conditions in Lombok, WNT Province (Mean \pm Sem)

\begin{tabular}{lcc}
\hline \multicolumn{1}{c}{ Semen characteristics } & Motile semen $(\mathrm{n}=52)$ & Static semen $(\mathrm{n}=46)$ \\
\hline Volume (ml) & $2,21 \pm 0,57^{\mathrm{a}}$ & $0,86 \pm 0,11^{\mathrm{b}}$ \\
$\mathrm{pH}$ & $6,38 \pm 0,07^{\mathrm{a}}$ & $6,80 \pm 0,06^{\mathrm{b}}$ \\
Concentration (x107 sperm/ml) & $187,94 \pm 15,39^{\mathrm{a}}$ & $144,01 \pm 11,24^{\mathrm{b}}$ \\
Live sperm (\%) & $96,63 \pm 0,31^{\mathrm{a}}$ & $94,46 \pm 0,48^{\mathrm{b}}$ \\
Abnormal spermatozoa (\%) & $7,40 \pm 0,79^{\mathrm{a}}$ & $11,39 \pm 1,01^{\mathrm{b}}$ \\
Bent tail (\%) & $3,60 \pm 0,55^{\mathrm{a}}$ & $5,98 \pm 1,04^{\mathrm{b}}$ \\
Coiled tail (\%) & $1,33 \pm 0,24$ & $2,02 \pm 0,36$ \\
Loose head (\%) & $2,48 \pm 0,40$ & $3,41 \pm 0,53$ \\
Reaction time (sec) & $45,54 \pm 10,58$ & $72,90 \pm 15,34$ \\
\hline
\end{tabular}

$\mathrm{n}$ : number of collected samples

Figures with similar superscript within the same row are not significantly different from each other at level $(\mathrm{p}<0.05)$.

The physical characteristics related to volume, $\mathrm{pH}$, concentration, live, total abnormal and bent tail of spermatozoa (Table 4) were significantly different between static semen and motile semen. Lower ejaculate volume, sperm concentration and live spermatozoa in static semen were also reported by other workers in Murrah buffalo bulls (Nainar et al., 1990; Kumar et al., 1993). In terms of reaction time, although it was higher in bulls donated static semen than that of bulls donated motile semen, the difference was not significant. This was consistent with the results of Kumar et al. (1993). Sexual excitement as indicator of reaction time is one of the factors markedly influencing semen production in dairy bulls (Collins et al. (1951). Our study revealed that bulls ejaculating static semen had longer reaction time and produced lower semen volume compared to bull ejaculating motile semen. This finding concurred well with Kumar et al. (1993) findings and similarlto Nainar et al. (1990) findings. However, the reaction time found in this study was different from Murrah buffalo bulls reaction time. The volume of semen in a group of static semen of swamp buffalo was significantly lower than motile semen. 


\section{CONCLUSION}

In conclusion, the characteristic of semen and spermatozoa in both motile and static semen of swamp buffalo in this study was still comparable to those reported by other experts in different breeds of buffalo. Further studies on the suitability of motile semen of swamp buffalo to be preserved in liquid and frozen states are needed.

\section{ACKNOWLEDGEMENT}

The authors are thankful to Directorate General of Higher Education, the Minstry of Science, Technology and Higher Education, Republic of Indonesia for providing financial support under Research for the Development of Science and Technology Scheme [grant number 181.A/SPP-IPTEK/UN18.12/PL/2017].

\section{REFERENCES}

Ahmed, M., S. Sinha, B.C. Deka, R.K. Biswas, G.C. Das, A. Dutta, P.K. Das and H. Mazumdar. 2015. Physical characteristics of swamp buffalo semen. Indian Vet. J. 92:4849.

Amin, M.R., M.R. Toelihere, T.L. Yusuf and P. Situmorang. 1999. Effect of cattle bull semen plasma on the the quality of swamp buffalo (Bubalus bubalis) frozen semen. Journal of Livestock and Veterinary Science. 4:143-147

Bhakat, M., T.K. Mohanty, A.K. Gupta and V.S. Raina. 2009. Effect of season and management on semen quality of breeding bulls- a review. Agric. Rev. 30:79-93
Capitan, S.S., G.S. Antiporda and V.G. Momongan. 1990. Reaction time, semen output and semen quality of buffalo bulls after pre-collection injection of prostaglandin F2 Alpha (PGF2 Alpha). Asian-Australasian Journal of Animal Sciences. 3:343346

Christensen, P., P.B. Brockhoff and H. Lehn-Jensen. 1999. The relationship between semen quality and the nonreturn rate of bulls. Reprod. Dom. Anim. 23:492-496

Collins, W.J., R.W. Bratton and C.R. Henderson. 1951. The relationship of semen production to sexual excitement of dairy bulls. Journal of Dairy Science. 34:224-227

Dixit, N.K., S.P. Agarwal, P.K. Agarwal and P.K. Dwaraknath. 1984. Seasonal variations in serum levels of thyroid hormones and their relation with seminal quality and libido in buffalo bulls. Theriogenologi. 22:497-507.

Fiaz, M., R.H. Usmani, M. Abdullah M. and T. Ahmad. 2010. Evaluation of semen quality of Holstein Friesian and Jersey bulls maintained under subtropical environment. Pak. Vet. J. 30:75-78

Ghodasara S.N., P.U. Gajbhiye, A.R. Ahlawat, and K.S. Murthy. 2016. Evaluation of fresh semen quality and predicting the number of frozen semen doses in Jaffrabadi buffalo bulls. Buffalo Bulletin. 35:65-72 
Gunarajasingam,

D., H.

Abeygunawardena, V.Y. Kuruwita, E.R.K. Perera and B.M.A.O. Perer. 1995. Characterization of semen of Nili-ravi buffalo bulls using standard and modified techniques. Tropical Agricultural Research. 7:159-167

Hafez, E.S.E. 1987. Semen evaluation. In: E.S.E. Hafez (Ed.). Reproduction in farm animal, $5^{\text {th }}$ Edition, Lea and Febiger, Philadelphia

Jainudeen, M.R., T.A. Bongso and S. Dass S. 1982. Semen characteristics of the swamp buffalo (Bus bubalis). Animal Reproduction Science. 4:213-217

Javed, M.T., A. Khan and R. Kausar. 2000. Effect of age and season on some semen parameters of Nili-Ravi buffalo (Bubalus bubalis) bulls. Vet. Arhiv. 70:83-94

Kiani, F.A., A. Yousaf, M.A. Zafar, M. Nawaz, Z. Akbar, M.R. Sohoo and A.S. Magsi 2014. Effect of age on physical characteristics of Kundhi buffalo bull semen. Int. J. Curr. Microbiol. App. Sci. 3:445-453

Koonjaenak, S., V. Chanatinart, S. Aiumlamai, T. Pinyopumimintr and H. Rodriguez-Martinez. 2007. Seasonal variation in semen quality of swamp buffalo bulls (Bubalus bubalis) in Thailand. Asian J. Androl. 9:92-101

Kumar, S., K.L. Sahni and G.S. Bistha. 1993. Cytomorphological characteristics of motile and static semen of buffalo bulls. Buffalo J. 2:117-127
Mahmoud, K.G.M., A.A.E. El-Sokary, M.E.A. Abou El-Roos, A.D. Abdel Ghaffar and M. Nawito M. 2013. Sperm characteristics in cryopreserved buffalo bull semen and field fertility. Iranian Journal of Applied Animal Science. 3:777-783

Nainar, A.M., B.M. Easwaran and V. Ulaganathan. 1990. Studies on nonmotile spermatozoa (static semen) in buffalo bull semen. Indian Vet. J. 67:133-136

Nuti, L. 1997. Techniques for Artificial Insemination of Goats. In: Youngquist, R.S. (Ed.), Current Therapy in Large Animal Theriogenology. W.B. Saunders Company, Philadelphia

Patel, B.R. and G.M. Siddiquee. 2013. Physical and morphological characteristics of Kankrej bull semen. Vet. World. 6:405-408

Ramadan, T.A., M.A. Tahab, B. Samak and A. Hassan 2009. Seasonal and monthly variations in semen characteristics of Egyptian buffalo bulls. Alex. J. Agric. Res. 54:13-23.

Sansone, G., M.J.F. Nastri, A. Fabbrocini. 2000. Storage of buffalo (Bubalus bubalis) semen. Animal Reproduction Science. 62:55-76 
Singh, P., B.P. Sengupta and V.N.

Tripathi. 2001. Effect of multiple showering and vitamin supplementation on sexual behaviour, quality and freezability of buffalo bull semen. Asian-Aust. J. Anim. Sci. 14:184-188 